\title{
ОДНОКЛІТИННІ ОРГАНІЗМИ РОДУ ЕIMЕRIA ТА ЇХ ВПЛИВ НА ОРГАНІЗМ ПТИЦІ І ХУТРОВИХ ЗВІРІВ
}

\author{
Довгій Ю. Ю., Рудік О. В.
}

\section{ВСТУП}

В останніх дослідженнях і публікаціях окремі вчені повідомляють, що паразитарні захворювання посідають третє місце у світі з-поміж хвороб птахів та хутрових звірів ${ }^{1}$.

Еймеріозами називають хвороби свійських і диких тварин, а також людини, що характеризуються гострим, підгострим або хронічним перебігом. Висока стійкість ооцист та цист най простіших до впливу факторів зовнішнього середовища i перепадів температури сприяє збереженню впродовж тривалого часу здатності доходити до інвазійної стадії та заражати тварин.

Найчастіше хворіють молоді тварини. Еймеріози проявляються загальним пригніченням, розладом діяльності шлунково-кишкового тракту, супроводжуються сильним проносом, іноді кривавим, із наступним виснаженням ураженої тварини. Еймеріози нерідко спричинюють ензоотії у кролів, птиці, телят, ягнят, свиней, завдаючи тваринництву відчутних економічних збитків ${ }^{2}$.

Згідно 3 даними світової ветеринарної статистики, втрати від еймеріозу у тваринництві становлять близько 1 млрд доларів щорічно. Найбільших економічних збитків у разі еймеріозів завдає падіж. Значну частину втрат становить також зниження продуктивності тварин. Так, хворі на еймеріоз телята втрачають до 27 кГ маси тіла, а ягнята - до 8,5 кг. Окрім того, значно погіршується якість м'яса, яєць ${ }^{3}$.

1 Євстаф'єва В.О., Клименко О.С., Хижня Л.Ю. Моніторинг кишкових паразитозів курей приватних господарств Полтавської області. Вісник Полтавської державної аграрної академії. 2010. № 4. С. 130-131.

${ }^{2}$ Вержиховський О., Колос Ю., Титаренко В. Епізоотичний стан птахівництва в Україні. Ветеринарна медицина України. 2007. № 6. С. 8-10.

${ }^{3}$ Jaromin-Glen K., Klapec G., Karamon J., Malicki J. \& Skowronska A. Division of Methods for Counting Helminthes Eggs and the Efficiency of these Methods. Lals of Agricultural and Environmental Medicine, 24 (1), 2017, 1-7. doi: 10/5604/ 12321966.1233891 
Еймеріози поширені повсюдно у всіх країнах, де займаються розведенням хутрових звірів та птиці ${ }^{4}$.

Сучасне птахівництво, кролівництво та нутрієвництво в Україні має динамічний розвиток і вже сьогодні практично повністю може задовольнити потреби населення держави у високоякісних продуктах харчування (м'ясі та яйцях). Цьому сприяє впровадження новітніх сучасних технологій вирощування, використання кращих вітчизняних і зарубіжних видів птиці та хутрових звірів, інвестиції, реконструкції наявних приміщень для вирощування i нове їх будівництво та ефективне лікування і профілактика ${ }^{5}$.

Ветеринарне забезпечення промислового птахівництва та кролівництва $є$ невід'ємною частиною технологічного процесу. Головне місце в цьому займають імунопрофілактика та лікувальні заходи, спрямовані на підвищення природної i специфічної резистентності до збудників інфекційних та інвазійних захворювань ${ }^{6}$.

Серед паразитів птахів та хутрових звірів одними 3 найбільш поширених і патогенних $є$ одноклітинні роду Eimeria. Еймеріоз характеризується високою летальністю, виснаженням тварин i зниженням імунітету до інфекційних та інвазійних захворювань. Загибель, затримка росту та розвитку перепелів, курей, кролів, порушення якості продукції в результаті еймеріозної інвазії призводять до значних економічних збитків ${ }^{7}$.

Ооцисти еймерій виділяються 3 фекаліями хворих постійно, починаючи вже 3 5-7-ої доби після інвазування. У боротьбі 3 еймеріозом тварин світова ветеринарна наука розробила i рекомендує практично безперервно застосовувати хіміопрепарати впродовж усього періоду вирощування. Проте активність багатьох еймеріостатиків за щоденного застосування поступово знижується

\footnotetext{
${ }^{4}$ Демина Н.В. Источники заражения кур эймериями. Энтомол. и паразитол. исслед. в Поволжье. Саратов, 2003. Вып. 2. С. 113-114.

${ }^{5}$ Коцюмбас I.Я., Сергієнко О.І., Ковальчик Л.М. Сучасні підходи до створення та застосування протипаразитарних препаратів. Ветеринарна медицина України. 2010. № 11. C. 14-17.

6 Интегрированная система контроля кокцидиоза. Птицеводство. 2004. № 8. C. $17-22$.

${ }^{7}$ Методичні рекомендації з діагностики, лікування та профілактики еймеріозу курей / А.Ю. Гірковий, М.В. Голубцова, В.В. Стибель, М.М. Данко // Затверджено науково-методичною радою Державної ветеринарної та фітосанітарної служби України (протокол № 1 від 19 грудня 2013 р.). 2014. 32 с.
} 
за рахунок резистентності збудників та імуносупресивної дії на імунну систему тварин ${ }^{8}$.

Система протиеймеріозних заходів у низці господарств України продовжує бути недостатньо ефективною. До цього часу особливості епізоотології та перебігу еймеріозної інвазії не вивчені, що перешкоджає розробленню ефективної системи боротьби з ним.

У зв'язку з цим нині актуальним є дослідження еймеріозу курей, перепілок та хутрових звірів з епізоотології хвороби, патогенезу, розроблення науково обгрунтованих заходів боротьби.

\section{1. Епізоотологія, патогенез та діагностика еймеріозу}

Було вивчено ситуацію щодо еймеріозу в Житомирській, Хмельницькій, Волинській і Київській областях України. Збудником даного захворювання $є$ одноклітинний паразит, який локалізуються в епітеліальних клітинах слизової оболонки в кишечнику птиці та хутрових звірів, а також в епітелії жовчних ходів печінки. Смертність хворих тварин може сягати від 70 до 100\%. Найбільш сприйнятливий до паразитів молодняк, зараженість якого сягає $80 \%$, а тварини більш тяжко хворіють.

Еймеріофауна характеризується неоднаковим видовим складом. Паразитують у кролів E. perforans, E. magna і E. stiedae, а в нутрій E. irresidua, E. perforans, E. magna, E. coecicola. Найпоширеніші збудники еймеріозу курей і перепілок на території Житомирщини та Київщині - це E. necatrix, E. tenella, E. acervuline, E. maxima.

Дослідженнями встановлено що хутрові звіри 3 першого дня народження заражаються еймеріозом під час ссання молока із забруднених сосків, до організму попадають збудники, але клінічного прояву не спостерігаємо за рахунок молочної дієти та надходження до організму антитіл матері. Подальше зараження відбувається через корм і воду, а також під час поїдання фекалій (посліду).

Основним шляхом зараження птиці еймеріями $є$ забруднені еймеріозною інвазією корми, вода та предмети догляду.

Поширенню даної хвороби сприяє скупчення птиці, кролів і нутрій на невеликих площах із підвищеною вологістю. Ооцисти в приміщення потрапляють також на взутті обслуговуючого персоналу.

${ }^{8}$ Luchese F.C., Perin, M., Aita R.S., Mottin V.D., Molento M.B., \& Monteiro S.G. (2007). Prevalence of Eimeria species in industrial and alternative bred chicken. Brazilian Journal of Veterinary Research and Animal Science, 44 (2), 81-86. 
Важлива місія в поширенні еймеріозу належить гризунам. Миші, щурі не заражаються еймеріями, однак, харчуючись кормовими рештками, заковтують і ооцисти, які проходить через шлунковокишковий тракт гризунів транзитом. Під час дефекації виділяють у навколишнє середовище збудник, як наслідок - інвазують клітки, корм, воду, інвентар.

Еймеріоз може протікати в гострій, хронічній і латентній формах.

За гострої форми спостерігається пригнічення, зниження апетиту, анемічність слизових оболонок, рідкі, мимовільні випорожнення містять домішки крові й слизу. Температура тіла підвищується. У гострий період перебігу еймеріозу за добу в зовнішнє середовище одна особина виділяє понад 60 млн ооцист, а в одному грамі фекалій вміст ооцист доходить до 300 тис.

За хронічного перебігу хвороби у тварин апетит збережений, але вони худнуть, відстають у рості та розвитку.

Латентний перебіг еймеріозу в основному спостерігається у дорослих тварин. Ця форма хвороби протікає без клінічних ознак.

Патогенетичний механізм еймеріозу - це пошкодження епітелію в кишечнику та жовчних протоках печінки. Під час ендогенної стадії розвитку еймерій руйнуються клітини тканин, в яких паразитує збудник, та утворюються дефекти слизової оболонки кишечнику, внаслідок чого оголюються капіляри та виникають кровотечі. У процесі хвороби розвивається гостре запалення. Внутрішньоклітинні стадії розвитку спричиняють механічну закупорку капілярів і лімфатичних судин, гіперемію та набряк кишкової стінки, солітарних фолікулів і Пейєрових бляшок.

Виникнення проносів у інвазованих тварин зумовлено посиленням моторики кишечника секрецією тканинної рідини в просвіт кишечника, як наслідок - подразнення рецепторів кишкової стінки. Під час діареї відбувається швидка евакуація вмісту кишечника, тому рідина, що знаходиться в хімусі, не встигає всмоктатись. У результаті випотівання ексудату, затрудненого всмоктування рідини в просвіті кишечнику в організмі виникає негативний водний баланс, що важливо за еймеріозу. Втрата води організмом більше 10-15\% може призвести до загибелі хворих тварин.

Дегідратація збільшує в'язкість крові, кількість еритроцитів і гемоглобіну збільшується, що створює труднощі для роботи серцево-судинної системи, а збільшення кількості серцевих скорочень і прискорення серцевого поштовху за еймеріозу слід розглядати як компенсаторне явище. 
Відторгнення зруйнованого епітелію внаслідок підвищення проникності капілярів призводить до виходу крові у просвіт кишечника, а масове розмноження еймерій у слизовій оболонці кишечника i розпад клітин призводить до того, що на мертвому білковому субстраті починає посилено розмножуватись гнильна мікрофлора, яка ще більше ускладнює запальні процеси в кишечнику. Під час руйнування епітелію кишечнику еймерії також руйнують і епітелій травних залоз, унаслідок чого функція всмоктування в місцях ураження порушується та виникає виснаження організму.

Рівень регенеративних властивостей і захисних функцій кроля, його реактивність залежать від повноцінності фізіологічного стану організму в цей момент та його індивідуальних особливостей. Тому всі фактори, що послабляють резистентність організму кролів, прямо або побічно сприяють розвитку еймерій.

Ефективне лікування хворих тварин можливе лише за умови вчасної постановки діагнозу. У випадку паразитарних захворювань діагноз можливо встановити в результаті виявлення збудника в організмі або виділеннях тварин.

Діагноз установлюють шляхом лабораторного дослідження: фекалій у нутрій та кролів за методом Дарлінга, КотельниковаХрєнова, Щербовича; для діагностики у курей і перепілок застосовують метод Фюллеборна та спосіб копрологічної діагностики гельмінтозів і еймеріозів за Довгієм; з наступним мікроскопічним виявленням ооцист еймерій.

За методом Довгія домішки та рослинні клітини забарвлюються в рожевий та червоний кольори, таким чином, спрощується процес мікроскопії та диференціації ооцист еймерій.

За посмертної діагностики проводять дослідження скрібків слизової оболонки кишечника та жовчних протоків печінки. За наявності характерних ознак ураження, а саме еймеріозних вузликів, проводять дослідження їхнього вмісту під малим та середнім збільшенням мікроскопа. У разі позитивного результату на предметному склі виявляють ооцисти еймерій.

\section{2. Особливості клінічного прояву та зміни}

\section{в показниках крові за еймеріозу}

Хвороба в хутрових звірів характеризується втратою апетиту, пригніченням, проносами, паралічами й судомами, зниженням апетиту, блідістю слизових оболонок, хиткістю рухів, слабкою руховою активністю, виснаженням тварин. 
Перші клінічні ознаки під час гострої формі еймеріозу - це пригнічення, зменшення, а потім і втрата апетиту. Кролі та нутрії стають малорухливими і більше лежать, спостерігається здуття черевця, болючість під час пальпації, поліурія. Видимі слизові оболонки стають блідими. Спочатку фекалії звичайної консистенції, а далі виділяються напіврідкими і містять велику кількість слизу, рідкі домішки крові. У деяких тварин розвивається риніт, кон'юнктивіт, судоми, параліч м'язів шиї, кінцівок. Хворі кролі відстають у рості й розвитку, шерсть стає тусклою та скуйовдженою.

Гострий перебіг хвороби, який у середньому продовжується до 14 діб, дуже часто закінчується смертю тварин, а за підгострої форми еймеріозу клінічний прояв менш характерний (згладжений), і захворювання розтягується до 30-35 діб.

Хронічна форма в середньому триває 30-45 діб і характеризується відставанням у рості й розвитку, періодичними проносами, які змінюються виділенням сформованих фекальних мас, схудненням. Тварини, які перехворіли еймеріозом, погано відгодовуються і за темпами росту й розвитку ніколи не досягають показників здорових.

У хутрових звірів найвищу екстенсивність та інтенсивність інвазії виявляли в січні, лютому та на початку березня серед усіх вікових груп. Кролі хворіють найчастіше з 2 до 4-хмісячного віку, а нутрії - $з$ 20-денного віку з піком інвазії у 2-3 місяці. Зараженість у кролів сягає 79\%, у нутрій різниця відповідно до віку: до 3 місяців $-73 \%$, дорослі особини - 25\%.

Найвища II у кролів віком 2-6 міс, а в нутрії - у віці 8-10 міс.

За результатами досліджень крові нутрій у гематологічних показниках кількість еритроцитів (Т/л) у хворих була нижчою порівняно з даними здорових: 4,23 \pm 0,38 відповідно до 4,39 $\pm 1,93$. За результатами лейкограми до i після лікування нами було відзначено: постлікувальне стабільне збільшення кількості базофілів $0,6 \pm 0,4 \%$ відносно $2,8 \pm 0,86$; зменшення еозинофілів $12,4 \pm 1,08$ відносно до 8,2 $\pm 6,58$; збільшення паличкоядерних нейтрофілів $5,8 \pm 1,07 \%$ відносно $6,2 \pm 0,58$; сегментоядерних нейтрофілів $24 \pm 1,1 \%$ відносно до $25,2 \pm 1,24 \%$; лімфоцитів $51,2 \pm 1,24 \%$ відносно 50,4 $\pm 1,12 \%$; моноцитів 5,2 $\pm 0,66 \%$ відносно до $5,0 \pm 0,51$.

Згідно з результатами в біохімічних показниках відзначали зміни вмісту гемоглобіну (г/л) також до лікування 99,36 $\pm 6,29$ відносно $122,45 \pm 14,17$ і загального білку (г/л) у сироватці крові нутрій після 
застосування еймеріостатика, порівняно з початковим значенням цей показник збільшився 80,3 $\pm 3,71$ відносно $69,1 \pm 4,0$; вміст альбумінів (г/л) також у ході досліду показав збільшення 28,18 $\pm 3,2$ відносно 26,85 $\pm 2,05$.

В інвазованих еймеріями кролів за даними наших морфологічних і біохімічних досліджень крові тварин установлено, що за еймеріозів зменшується кількість еритроцитів до 4,23 $\pm 0,38$ порівняно зі здоровими кролями 5,2 \pm 0,4 Т/л, гемоглобіну - до $99,36 \pm 6,29$ порівняно зі здоровими кролями $110,6 \pm$ 7,9 г/л, рівень загального білка в сироватці крові у хворих кролів становив $54,80 \pm$ 2,22 г/л порівняно зі здоровими кролями $68,58 \pm 10,12$ г/л; вміст альбуміну в крові у дослідних кролів дорівнював 42,25 $\pm 2,87$ порівняно зі здоровими кролями 60,28 $\pm 1,14$ г/л. Активність АсАТ була зниженою в крові хворих і становила 239,85 $\pm 41,07$ порівняно зі здоровими 256,5 $\pm 39,7$ ОД/л.

Результати морфологічних та біохімічних досліджень засвідчили, що у нутрій підвищення кількості еритроцитів, вмісту гемоглобуліну характеризує нормалізацію еритропоезу після лікування, а підвищення рівня вмісту загального білку, альбумінів та глобулінів свідчило про відновлення функції печінки; підвищення кількості таких показників у кролів, як еритроцити, паличкоядерні й сегментоядерні нейтрофіли, моноцити, до показників клінічно здорових кролів свідчить про звільнення організму від токсинів, які виникли внаслідок загибелі еймерій.

Для визначення впливу еймерій на організм курей і перепілок порівнювали клінічні та гематологічні показники здорових та інвазованих еймеріями (E. necatrix, E. tenella, E. acervuline, E. maxima) птахів.

Хвора птиця відстає в рості й розвитку, пригнічена, малорухлива, скупчується в місцях обігріву, спостерігаються проноси. Дослідження показали, що у 53\% хворих курей впродовж місяця спостерігались періодичні проноси, у 47\% - загальне пригнічення, у $13 \%$ - анемічність гребеня i сережок. При цьому яєчна продуктивність птахів була нижчою на 18,6\%.

У хворих перепілок спостерігали періодичні проноси в 65\%, пригнічення - у 50\%, анемічність видимих слизових оболонок i гребеня - у $30 \%$. Несучість досліджуваних самочок була на 22,7\% нижчою за аналогічний показник у групі здорових птахів. 
Проведене щоденне дослідження змін температури тіла, пульсу та частоти дихальних рухів у інвазованих птахів дозволило визначити загальний стан курей (рис. 1).

Результати дослідження температури тіла, пульсу і частоти дихання вказали на тенденцію до підвищення значень цих показників, однак залишались у межах норми (B.I. Левченко та ін., 2004).

Подібні результати були отримані під час дослідження перепілок, хворих на еймеріоз. Але оскільки в літературних джерелах немає нормативів щодо температури, частоти пульсу та дихання перепілок, ми порівняли дані хворих і здорових птахів (рис. 2).



Рис. 1. Середня температура тіла, частота пульсу та дихання здорових і хворих на еймеріоз курей

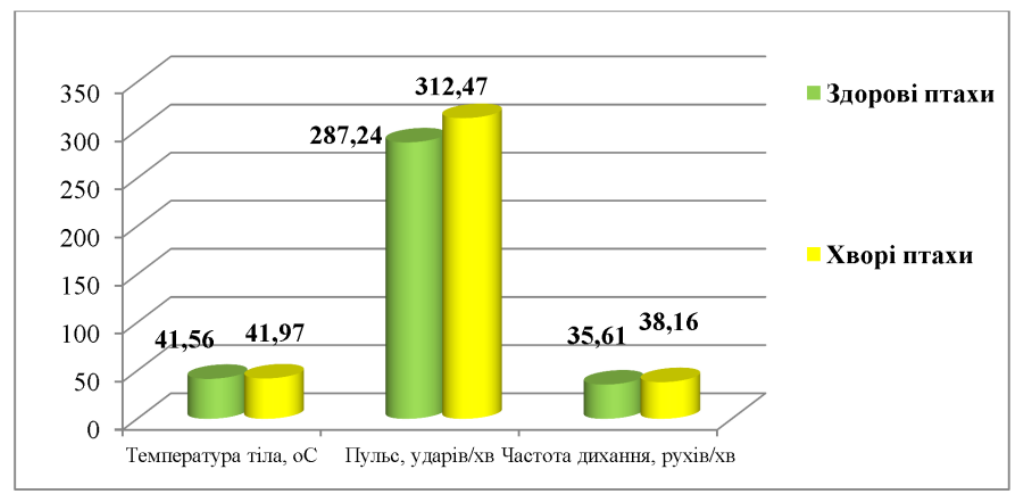

Рис. 2. Середня температура тіла, частота пульсу та дихання здорових і хворих на еймеріоз перепілок 
Отримані дані вказують, що в організмі хворих птахів, уражених еймеріозною інвазією, спостерігається хронічне запалення.

Дослідження крові птиці показало, як впливає еймеріозна інвазія на гематологічні показники. Результати дослідження змін гематологічних показників вказують на те, що у хворих курей спостерігається підвищення кількості лейкоцитів на 16,2\%.

При цьому в лейкограмі крові інвазованих курей відмічено підвищення вмісту базофілів на 31,6 та еозинофілів на 21,4 та зниження вмісту псевдоеозинофілів на 30,7 та моноцитів на 31,2\%.

Морфологічні показники крові перепілок, хворих на еймеріоз, вказують на зниження кількості еритроцитів на 8,3\% та підвищення кількості лейкоцитів на 17,4\%.

У лейкограмі перепілок, хворих на еймеріоз, спостерігали базофілію у 6,3\% та еозинофілію у $11,1 \%$ від загальної кількості хворих.

Незначне, але достовірне зниження кількості еритроцитів у крові птиці можна пояснити трофічним впливом еймерій, що в процесі живлення призвели до дефіциту білків, а також токсичним впливом метаболітів паразитів, що проявляється у вигляді пригнічення функції кісткового мозку. Лейкоцитоз у крові $\epsilon$ реактивним i виникає за рахунок стимуляції органів лейкопоезу продуктами розпаду тканинних білків, що потрапляють у кров унаслідок механічного впливу еймерій, а також токсинами і метаболітами паразитів унаслідок токсичного впливу.

Підвищення вмісту базофілів у крові птахів за еймеріозу вказує на розвиток алергічного процесу в організмі. Еозинофілію у хворих курей і перепілок можна пояснити алергічним впливом соматичних токсинів та метаболітів еймерій 3.

Також важливими для вивчення особливостей патогенезу еймеріозної інвазії були зміни біохімічних показників профілю крові птиці.

3 результатів біохімічного дослідження крові курей відмічаємо зниження вмісту гемоглобіну на $12,0 \%$ та альбумінів у сироватці крові на 13,4\%, концентрації загального кальцію - на 9,6\%, креатиніну - на 20,7\%, сечової кислоти - на 40,3\%, а також активності ферментів АлАТ - на 26,8\% і ЛФ - на 15,5\%, АсАТ - на 12,9\%.

Біохімічне дослідження крові перепілок показало зниження вмісту гемоглобіну на $15,1 \%$. У перепілок відмічали гіпокальціємію на 11,5\% та підвищення активності фермента АсАТ на 16,1\%. У всіх інвазованих перепілок установлено підвищення сечової кислоти на $13,0 \%$, а також активності АлАТ - на 10,5\%. 
Отримані дані ми можемо пояснити тим, що анемія у птахів, хворих на еймеріоз, спричинена трофічним і токсичним впливом паразитів, що підтверджують й інші науковці.

Зниження концентрації загального білка, особливо альбумінової його фракції, насамперед спричинене трофічним впливом еймерій, які в процесі живлення в кишечнику хазяїна поглинають значну кількість поживних речовин, у тому числі й білка. Також має місце факт порушення секреторної функції шлунку, кишечника та підшлункової залози i, як наслідок, недостатнього перетравлення білка і всмоктування амінокислот у кишечнику в результаті паразитування еймерій. Виражене зниження концентрації альбумінів у сироватці крові хворих курей і перепілок пояснюється порушенням ïx синтезу в печінці, а отже, ураженням печінки внаслідок токсичного впливу метаболітів і соматичних токсинів паразитів.

Одночасне підвищення активності АлАТ, АсАТ і ЛФ у сироватці крові відбувається зазвичай у результаті інвазійного цитолізу гепатоцитів.

Підвищена концентрація креатиніну в крові курей є ознакою порушення ниркових видільних функцій. Цей факт підтверджується також збільшенням вмісту сечової кислоти в сироватці крові птахів, хворих на еймеріоз.

Незначне, але достовірне зниження вмісту кальцію в сироватці крові курей і перепілок за еймеріозу пояснюється порушенням засвоєння цього елементу з корму за рахунок розладу травлення.

Таким чином, зміни біохімічних показників у крові курей i перепілок, хворих на еймеріоз, вказують на порушення гемопоезу та всмоктування поживних речовин у шлунково-кишковому тракті, дисфункцію печінки, ниркову недостатність.

\section{3. Вплив дезінвазійних засобів на ооцисти еймерій}

Для оздоровлення господарств, що займаються вирощуванням хутрових звірів, курей і перепелів, тільки застосувати еймеріостатик недостатньо для боротьби з еймеріозом. Науковцями описано, що приміщення, клітки, де утримують хутрових звірів та птахів, інвентар контаміновані ооцистами еймерій та залишаються стаціонарним джерелом інвазії. У боротьбі з еймеріозом важливе значення має профілактика хвороби й дотримування зоогігієнічних правил утримання тварин. 
Перш за все потрібно звернути увагу на покращення санітарногігієнічних умов утримання: щодня чистити клітки, напувалки, годівниці, інвентар. Необхідно дотримуватись параметрів мікроклімату в клітках, слід установити сітчасту підлогу з розміром вічок $18 \times 18$ мм, через які будуть вільно видалятися продукти життєдіяльності тварин. Молодняк утримують ізольовано від дорослих тварин.

Ферма повинна працювати в режимі підприємства закритого типу. Вхід до неї і вихід дозволяється тільки через санпропускники. Всі роботи проводяться тільки в спецодязі й спецвзутті. В'їзд і виїзд автотранспорту здійснюється через дезбар'єр (глибина ванни 40 см, ширина $250 \mathrm{~cm}$, довжина $800 \mathrm{~cm}$ ). Ванну наповнюють водою (взимку - 15-20\%-им розчином повареної солі), в яку додають необхідну кількість дезінфікуючої речовини (гідроокис натрію, гіпохлорит натрію, глутаровий альдегід тощо).

Трупи тварин розтинають у спеціально відведеному приміщенні при ветеринарному пункті, а потім знешкоджують спалюванням. Клітки після видалення хворої тварини або трупа обов'язково дезінфікують.

Після покупки та завезення на ферму тварин карантинують протягом 30-ти діб. Перед висадкою тварин у карантинне приміщення їх ретельно клінічно оглядають. У період карантинування кролів, нутрій, перепілок та курей 3 профілактичною метою обробляють проти еймеріозу. За карантинним відділенням закріпляють спеціально виділених робітників, яких забезпечують окремим інвентарем і спецодягом.

Територію ферми та всіх виробничих об'єктів слід постійно утримувати в чистоті й систематично дезінфікувати. Перед дезінфекцією обов'язково проводять ретельне механічне очищення приміщень, кліток, годівниць, напувалок, інвентарю. Механічне очищення - це найважливіший процес у дезінфекційних заходах, від його якості залежать ефективність дезінфікуючих засобів. Перед проведенням механічного очищення приміщення зрошують водою для запобігання розсіювання збудників із пилом.

Одним із найдієвіших профілактичних заходів $\epsilon$ дезінвазія, оскільки знезараження довкілля $\epsilon$ важливим фактором розриву ланок епізоотичного ланцюга паразитарних захворювань, що сприяє запобіганню інвазування кінцевих живителів. Для хутрових та птахівничих ферм актуальним є питання дезінфекції та дезінвазії, оскільки це - одна 3 головних умов гігієни утримування тварин і виробництва 
екологічно безпечних продуктів харчування. Найпоширенішим способом нанесення дезінфектантів на поверхні є обприскування. Для цього можна використати гідропульти різних систем, ручні обприскувачі й дезінфекційні установки. У присадибних господарствах із цією метою можна використати звичайний віник. Під час проведення дезінфекції слід дотримуватися заходів особистої гігієни (працювати в спецодязі, респіраторі або марлевій пов'язці, гумових рукавичках, чоботах й обов'язково в головному уборі).

Отже, пошук та апробація нових ефективних i екологічно безпечних дезінвазаторів $є$ актуальною проблемою для сучасної ветеринарної паразитології.

Зважаючи на вищевикладене, ми вирішили дослідили дію дезінфектантів на хутрових фермах - бровадезу-20 та кристалу-1000 (виробництво НВФ «Бровафарма»). Проведені дослідження свідчать про негативний вплив даних препаратів на ооцисти курей та індиків, що підтверджує доцільність вивчення його дії на еймерії тварин інших видів.

У визначенні впливу бровадезу-20 та кристалу-1000 на збудників еймеріозу ми враховували зміни в морфології ооцист після обробки їх водними розчинами препаратів відповідної концентрації.

Після дезінвазії тест-проб 0,25\%-им розчином бровадезу-20 були виявлені: 7 ооцист E. stiedae зі зміненою формою і 2 - із незміненою (IE становила 77,78\%); 7 ооцист E. perforans втратили колір, у 3-х спостерігали «ефект тіні», ще 7 були гомогенізовані; без змін залишилося 6 ооцист (IE $=73,91 \%)$. Отже, середня ефективність бровадезу-20 становила $71,9 \%$.

У разі застосування 1,0\%-ого розчину бровадезу-20 протягом 75 хв. виявили 7 гомогенізованих ооцист E. stiedae, 2 без змін $(\mathrm{IE}=77,78 \%) ; 6$ гомогенізованих ооцист E. perforans, 3 без змін $(\mathrm{IE}=66,67 \%)$. Середня IE становила 72,23\%. За експозиції цього препарату протягом 24 год. виявили 5 гомогенізованих ооцист E. stiedae, 6 - 3 «ефектом тіні», 1 - без змін (IE =91,67\%); 9 гомогенізованих оцист $E$. perforans, 2 - 3 «ефектом тіні», 2 - без змін (IE $=84,62 \%)$. Середня IE становила $88,15 \%$.

Таким чином, найменший ефект на ооцисти E. stiedae та E. perforans проявив 0,3\%-й розчин кристалу-1000, що вказує на його непридатність для відповідної дезінвазії. Решта досліджуваних розчинів показали досить високий дезінвазійний ефект щодо збудників еймеріозу кролів із максимальним виявленням через 24 год. 
Отже, високу дезінвазійну ефективність щодо збудників еймеріозів кролів має 2\%-ий розчин кристалу-1000 та 1-1,5\%-ні розчини бровадезу-20.

Ми вирішили також дослідити дію дезінфектантів екоцид $\mathrm{C}$ та арквадез-плюс у різних концентраціях на ооцисти збудників еймеріозу птиці. Перед тестуванням зазначених препаратів безпосередньо в клітках та приміщеннях для утримання норок та кролів, перепелів та курей ми провели дослідження їх впливу на ооцисти збудників E. necatrix, E. tenella, E. acervuline, E. maxima в лабораторних умовах.

Засіб екоцид С застосовували у 0,5\%-ій концентрації для профілактичної дезінфекції приміщень та інвентаря в присутності тварин, у 1,0\%-ій - для планових дезінфекцій приміщень i в 1,5\%-ій - для дезінвазії після профілактичної обробки проти паразитів. Для проведення науково-господарського експерименту було вирішено випробувати в лабораторних умовах дезінвазійну ефективність екоциду C саме в цих трьох концентраціях, за експозиції 30 та 60 хв.

Препарат екоцид С у 1,0\%-ій концентрації в лабораторних умовах призвів до лізису або ушкодження 39,0\% ооцист еймерій через 30 хв. та $67,1 \%$ - через 60 хв. після обробки. Підвищення концентрації розчину до $1,5 \%$ дозволило підвищити ці показники до 82,2 та 94,1\% відповідно.

Арквадез-плюс згідно з настановою використовується у вигляді 1,5\%-го, 2,0\%-го та 2,5\%-го розчину. Дію препарату в різних концентраціях випробовували за експозиції 30 та 60 хв.

Препарат арквадез-плюс у 2,0\%-ій концентрації в лабораторних умовах призвів до лізису або ушкодження $36,1 \%$ ооцист еймерій через 15 хв. та 54,4\% - через 60 хв. після обробки. Підвищення концентрації розчину до $2,5 \%$ дозволило досягнути показників 65,1\% 93,1\% відповідно.

Як видно з результатів досліджень, 1,0\%-ий екоцид С та арквадезплюс у 1,5\%-ій концентрації проявили незначний дезінвазійний ефект щодо збудників еймеріозу птиці. Це засвідчила гомогенізація та ушкодження лише 20,1 та 25,2\% ооцист відповідно навіть за умови експозиції 60 хв. Тому було вирішено продовжити науковогосподарський дослід 3 дезінвазійними розчинами у виробничих умовах у концентраціях 1,0 і 1,5\% для екоциду С та 2,0 і 2,5\% - для арквадез-плюс. 
Через 30 хв. після обробки кліток, де утримують птицю, 1,0\%-им розчином екоциду C IE засобу щодо ооцист еймерій становила 43,2\%. За 60-хвилинній експозиції IE препарату зросла до 70,4\%. Підвищення концентрації екоциду С до 1,5\% дозволило підвищити його IE до 85,1\% за експозиції 30 хв. та 95,3\% після 60 хв.

Препарат арквадез-плюс у 2,0\%-ій концентрації щодо збудників еймеріозу птиці проявив ефективність $46,0 \%$ через 30 хв. та 64,1\% через 60 хв. Підвищення концентрації цього засобу до 2,5\% дозволило збільшити IЕ до 76,1 та 96,2\% відповідно.

3 точки зору економічної ефективності, враховуючи реалізаційні ціни на досліджувані засоби станом на листопад 2020 р., вартість обробки кліток для утримання птиці 1,5\%-им розчином екоциду С (у розрахунку 300 мл розчину на $1 \mathrm{~m}^{2}$ ) становить 7,30 грн за $1 \mathrm{~m}^{2}$ площі. Вартість аналогічної обробки 2,5\%-им розчином препарату

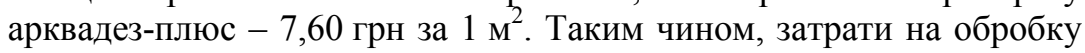
досліджуваними засобами суттєво не відрізняються.

Отже, аналізуючи отримані результати, можна стверджувати, що дезінфектанти бровадез-20 і кристал-1000 мали виражені дезінвазійні властивості проти ооцист Eimeria spp. Найбільш ефективною $є$ обробка кліток для утримання курей і перепілок 1,5\%-им розчином бровадезу-20 та 2,0\%-им - кристалу-1000 за умови експозиції 24 год.

Одночасно з дезінфекцією необхідно проводити й дезінсекцію заходи, спрямовані на знищення шкідливих комах (кліщі, воші, мухи, комарі). У кролівничих господарствах для дезінсекції можна використовувати водні емульсії неоцідолу, стомазану, неостомазану, ціодрину, метатіону, діазаніну тощо. У загальному плані ветеринарно-санітарних заходів необхідно обов'язково передбачати боротьбу з гризунами, відловлювання бродячих собак і котів, проведення дегельмінтизації та вакцинації сторожових собак.

\section{ВИСНОВКИ}

Збудники еймеріозу хутрових звірів, курей та перепілок - одноклітинні паразити ряду Coccidia, родини Eimeriidae, роду Eimeria.

Еймеріоз - поширене в Україні захворювання хутрових звірів та птиці. Паразитують у дослідних кролів та нутрій Волинської та Хмельницької областей такі збудники: кролів E. perforans, E. magna і E. stiedae, а в нутрій - E. irresidua, E. perforans, E. magna, E. coecicola. У курей та перепілок еймеріоз має чітку сезонність, максимальна інтенсивність інвазії припадає на літній та осінній 
період року, в хутрових звірів це також осінній період року. Еймеріями найчастіше уражуються кури віком 1,5-6 міс. та перепілки - від 10 діб до 2 міс. Частіше еймеріоз курей і перепілок проявляється в чистому вигляді, але зустрічаються випадки асоціації еймерій зі збудниками гетеракозу та аскаридіозу птиці. Найпоширеніший варіант комбінації збудників еймеріозу курей i перепілок на території Житомирщини - E. necatrix, E. tenella, E. acervuline, E. maxima.

Для прижиттєвої діагностики еймеріозу курей i перепілок доцільно використовувати «Спосіб копрологічної діагностики гельмінтозів і еймеріозів». За цього способу як флотаційну рідину застосовують $35 \%$-ий розчин цукру з додаванням розчину Люголя в розрахунку 1:5-1:10.

Основним шляхом зараження еймеріями тварин $\epsilon$ забруднені еймеріозною інвазією корми, вода та предмети догляду. Поширенню даної хвороби сприяє скупчення птиці та хутрових звірів на невеликих площах з підвищеною вологістю.

Еймеріоз у птиці та хутрових звірів може протікати як у гострій, так і у хронічній та латентній формах.

Паразитування еймерій в організмі тварин призводить до загального пригнічення та зниження продуктивності, розвитку запальних і алергічних процесів, порушення гемопоезу, а також морфофункціонального стану стінок кишечника та печінки.

\section{АНОТАЦІЯ}

Дослідження присвячене вивченню питання щодо еймеріозу курей, перепелів, кролів та нутрій на території Житомирської, Хмельницької, Волинської та Київської областей України. Видовий склад збудника даного захворювання варіюється в залежності від регіону, виявлено такі збудники: у кролів - E. perforans, E. magna і E. stiedae, в нутрій - E. irresidua, E. perforans, E. magna, E. coecicola. Найпоширеніші збудники серед курей та перепілок на території Житомирщини та Київщини - це E. necatrix, E. tenella, E. acervuline, E. maxima.

Збудник локалізувався в епітеліальних клітинах слизової оболонки в кишечнику птиці й хутрових звірів, а також в епітелії жовчних ходів печінки. Смертність хворих дорослих особин сягала $79 \%$, а в молодняка $-87 \%$.

Дослідженнями встановлено, що нутрії та кролі заражаються 3 першого дня народження під час ссання молока із забруднених 
фекаліями сосків. Зараження курей та перепелів еймеріями відбувалося через корм, воду та предмети догляду і взуття персоналу.

Встановлено, що еймеріоз може протікати в гострій, хронічній і латентній формах.

Хвороба у хутрових звірів характеризується втратою апетиту, пригніченням, проносами, паралічами й судомами, блідістю слизових оболонок, слабкою руховою активністю, виснаженням тварин. Фекалії звичайної консистенції, а надалі містять велику кількість слизу та рідкі домішки крові. У поодиноких випадках у хворих нутрій та кролів розвивається риніт, кон'юнктивіт, судоми, параліч м'язів шиї, кінцівок.

Кролі хворіють найчастіше з 2 до 4-хмісячного віку, а нутрії з 20-денного віку з піком інвазії у 2-3 місяці.

За результатами досліджень крові нутрій у гематологічних показниках спостерігається зменшення кількості еритроцитів, еозинофілів та збільшення кількості базофілів паличкоядерних, сегментоядерних нейтрофілів, лімфоцитів, моноцитів.

Згідно з результатами в біохімічних показниках відзначали зміни вмісту гемоглобіну, загального білку, альбумінів.

У хворих перепілок та курей спостерігали: періодичні проноси в $65 \%$, пригнічення - у 50\%, анемічність видимих слизових оболонок і гребеня - у 30\%. Несучість досліджуваних самочок була на $22,7 \%$ нижчою за аналогічний показник у групі здорових птахів.

Отримані дані вказують, що в організмі хворих птахів, уражених еймеріозною інвазією, спостерігається хронічне запалення.

Результати дослідження зміни гематологічних показників указують на те, що у хворих курей спостерігається підвищення кількості лейкоцитів, базофілів та еозинофілів і зниження вмісту еритроцитів, псевдоеозинофілів та моноцитів.

Морфологічними показниками крові перепілок, хворих на еймеріоз, встановлено зниження кількості еритроцитів та підвищення кількості лейкоцитів. У лейкограмі перепілок спостерігали базофілію та еозинофілію.

Незначне зниження кількості еритроцитів у крові птиці можна пояснити трофічним впливом еймерій, що в процесі живлення призвели до дефіциту білків, а також токсичним впливом метаболітів паразитів, що проявляється у вигляді пригнічення функції кісткового мозку. Лейкоцитоз у крові курей та перепелів $\epsilon$ реактивним і виникає за рахунок стимуляції органів лейкопоезу 
продуктами розпаду тканинних білків, що потрапляють у кров унаслідок механічного впливу еймерій, а також токсинами i метаболітами паразитів унаслідок токсичного впливу.

3 результатів біохімічного дослідження крові курей відзначаємо зниження вмісту гемоглобіну, альбумінів, загального кальцію, креатиніну, сечової кислоти, а також активності ферментів АлАТ, ЛФ та АсАТ.

Біохімічне дослідження крові перепілок показало зниження вмісту гемоглобіну, загального кальцію та підвищення активності фермента АсAТ. У всіх інвазованих перепілок установлено підвищення сечової кислоти, а також активності АлАТ.

Отримані дані ми можемо пояснити тим, що у перепелів, хворих на еймеріоз, зміни показників крові спричинені трофічним і токсичним впливом паразитів на організм, що підтверджують й інші науковці.

У визначенні впливу бровадезу-20 та кристалу-1000 на збудники еймеріозу кролів та нутрій найменший ефект на ооцисти $E$. stiedae та $E$. perforans проявив $0,3 \%$-й розчин кристалу- 1000 , що вказує на його непридатність для відповідної дезінвазії. Решта досліджуваних розчинів проявили високу дезінвазійну ефективність, а саме 2\%-ий розчин кристалу- 1000 та $1-1,5 \%$-ій розчини бровадезу-20.

Досліджено дезінфектанти екоцид С та арквадез-плюс у різних концентраціях на ооцисти збудників еймеріозу птиці.

Препарат екоцид С у 1,0\%-ій концентрації в лабораторних умовах призвів до лізису або ушкодження 39,0\% ооцист еймерій через 30 хв. та 67,1\% - через 60 хв. після обробки. Підвищення концентрації розчину до $1,5 \%$ дозволило підвищити ці показники до 82,2 та 94,1\% відповідно.

Препарат арквадез-плюс у 2,0\%-ій концентрації в лабораторних умовах призвів до лізису або ушкодження $36,1 \%$ ооцист еймерій через 15 хв. та 54,4\% - через 60 хв. після обробки. Підвищення концентрації розчину до $2,5 \%$ дозволило досягнути показників $65,1 \%$ та 93,1\% відповідно.

\section{ЛІТЕРАТУРА}

1. Свстаф'єва В.О., Клименко О.С., Хижня Л.Ю. Моніторинг кишкових паразитозів курей приватних господарств Полтавської області. Вісник Полтавської державної аграрної академї. 2010. № 4. C. 130-131. 
2. Вержиховський О., Колос Ю., Титаренко В. Епізоотичний стан птахівництва в Україні. Ветеринарна медицина Украӥни. 2007. № 6. C. $8-10$.

3. Division of Methods for Counting Helminthes Eggs and the Efficiency of these Methods. Lals of Agricultural and Environmental Medicine / K. Jaromin-Glen et al. 2017. 24 (1). 1-7. doi: 10/5604/ 12321966.1233891.

4. Демина Н.В. Источники заражения кур эймериями. Энтомологические и паразитологические исследования в Поволжье. Саратов, 2003. Вып. 2. С. 113-114.

5. Коцюмбас І.Я., Сергієнко О.І., Ковальчик Л.М. Сучасні підходи до створення та застосування протипаразитарних препаратів. Ветеринарна медицина Украӥни. 2010. № 11. С. 14-17.

6. Интегрированная система контроля кокцидиоза. Птицеводство. 2004. № 8. С. 17-22.

7. Методичні рекомендації з діагностики, лікування та профілактики еймеріозу курей / А.Ю. Гірковий та ін. 2014. 32 с.

8. Prevalence of Eimeria species in industrial and alternative bred chicken. Brazilian Journal of Veterinary Research and Animal Science I F.C. Luchese et al. 2007. 44 (2). 81-86.

\section{Information about the authors: Dovhiy Yu. Yu.,} Doctor of Veterinary Sciences, Professor, Head of the Department of Parasitology, Veterinary-Sanitary

Expertise and Zoohygiene of the Faculty of Veterinary Medicine Polissia National University 7, Staryi blvd, Zhytomyr, 10002, Ukraine

Rudik O. V., PhD Student at the Department of Parasitology, Veterinary-Sanitary Expertise and Zoohygiene of the Faculty of Veterinary Medicine Polissia National University 7, Staryi blvd, Zhytomyr, 10002, Ukraine 